\title{
Stock assessment of the Indian mackerel Rastrelliger kanagurta (Cuvier, 1817) from Muscat coast, Oman
}

\author{
N. JAYABALAN*, S. ZAKI, A. AL-MARZOUQI AND F. AL-KIYUMI \\ Marine Science and Fisheries Centre, Ministry of Agriculture and Fisheries Wealth, P.O. Box 427 \\ P.C. 100, Muscat, Sultanate of Oman \\ *Alga Marine Pvt. Ltd., 7 Velder Street, Anna Salai, Chennai - 600 002, Tamil Nadu, India \\ e-mail:maljaya2@yahoo.com
}

\begin{abstract}
Assessment of age, growth and stock parameters was carried out for the Indian mackerel Rastrelliger kanagurta (Cuvier) along the Muscat coast of Oman between October 2007 and September 2009. The length-weight relationship of the fish indicated the ' $a$ ' value as 0.0101 and ' $b$ ' value as 3.0589. The length based von Bertalanffy growth (VBG) parameters $\mathrm{L}_{\infty} \mathrm{K}$ and $\mathrm{t}_{0}$ estimated were $37.54 \mathrm{~cm}, 1.0 \mathrm{y}^{-1}$ and $-0.17 \mathrm{y}$ respectively. The estimates of mortality rates showed the annual total mortality (Z) to be 2.98, the natural mortality (M) 1.62 and fishing mortality (F) 1.36 . The MSY estimated by Cadima's estimator was $859 \mathrm{t}$ and the predicted value by yield analysis stood at 1,273 t. The calculated exploitation rate (E) was 0.46. The $\mathrm{Yw} / \mathrm{R}$ at $\mathrm{F}=1.6$ was $48 \mathrm{~g}$. Estimates of higher MSY than the current yield, lower fishing mortality than natural mortality and lower $\mathrm{E}$ indicate scope for increase in yield of $R$. kanagurta from Muscat region.
\end{abstract}

Keywords: Age, Growth, Muscat coast, Rastrelliger kanagurta, Stock assessment

\section{Introduction}

Sultanate of Oman is endowed with a coastline of 3,165 km bordering the Arabian Sea, Oman Sea and Arabian Gulf and has about 533,180 $\mathrm{km}^{2}$ of EEZ. The fisheries sector of Oman is mainly traditional subsistence oriented one, contributing less than $1 \%$ of GNP, but is second next to oil contributing to the economy of the country. Fish production in Oman registered a remarkable growth from $94893 \mathrm{t}$ in 1985 to $158789 \mathrm{t}$ in 2009 and the value rose from RO 25 million $(1 \mathrm{RO}=2.6 \mathrm{USD})$ to an all-time high of RO 104.6 million in the corresponding years (GoSO, 2009). Of the total fish production of the country, nearly $84 \%$ of catches come from the artisanal fisheries and the rest contributed by licensed industrial fleet (GoSO, 2009).

The contribution of small pelagics to the annual total fish landings of Oman varied from 21.4 to $51.3 \%$ between 1995 and 2009 (GoSO, 2009). Among the small pelagics of Oman, the Indian mackerel Rastrelliger kanagurta (Cuvier, 1817) is an important species (Randall, 1995). Its contribution to the total marine fish production of Oman varied from 1.9 to $6.9 \%$ between 1998 and 2009 and the annual average catch for the years 2000-2009 stood at $5334 \mathrm{t}$ (GoSO, 2007; 2009). This indicates that the Indian mackerel fishery is developing in the country and requires judicious resource use to the fullest potential.
Indian mackerel is caught from the Sea of Oman by artisanal gears such as gillnets (of various mesh sizes up to $75 \mathrm{~mm}$ ), seine nets (cod end mesh 9-12 $\mathrm{mm}$ ) and castnets (mesh size $21 \mathrm{~mm}$ ) using small boats (5 to $9 \mathrm{~m}$ LOA) fitted with outboard engines and the fishing activity is primarily confined to a depth up to $50 \mathrm{~m}$. Along the coast of Sea of Oman, Muscat is an important fish landing centre and the estimated annual landings of $R$. kanagurta from this coast for the period 2000-2009 varied from $419 \mathrm{t}$ in 2002 to $1025 \mathrm{t}$ in 2007 (GoSO, 2009). Though the fish is caught almost the year round during south-west monsoon months (June-August/September), the fishery operates at a low key due to rough seas. Information on the stock of R. kanagurta from Sohar coast bordering the Sea of Oman is available (Jayabalan et al., 2014). However, no attempt has been made to study the stock characteristics of $R$. kanagurta from the Muscat coast. As reliable stock estimates are needed for successful development and management of Indian mackerel fisheries along the Muscat coast, the present study on age, growth and stock assessment was undertaken for two years during 2007-2009.

\section{Materials and methods}

Altogether, 3804 specimens of $R$. kanagurta captured from Muscat coast (Fig. 1) during October 2007-September 2009 were brought to the laboratory and the total length $( \pm 1 \mathrm{~mm})$ of each specimen was measured 


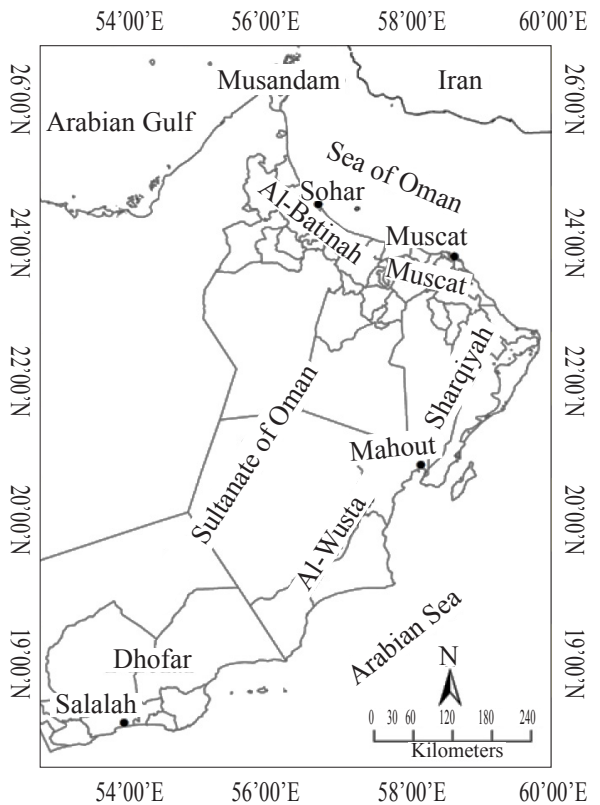

Fig. 1. Map showing the Muscat coast

using a fish measuring board. To estimate the lengthweight relationships of males and females, 810 specimens (406 females and 404 males) were used employing the equation, $\mathrm{W}=\mathrm{aL}^{\mathrm{b}}$ (Jayabalan et al., 2014). While the size of females ranged from 17.3 to $34.5 \mathrm{~cm}$ and weight from 54 to $476 \mathrm{~g}$, the size of males varied from 17.5 to $33 \mathrm{~cm}$ and weight from 41 to $448 \mathrm{~g}$. The lengthweight relationships of males and females were tested with Analysis of Covariance (ANCOVA) (Snedecor and Cochran, 1967) for significant difference at 5\% level.

von Bertalanffy growth (VBG) parameters such as $\mathrm{L}_{\infty}, \mathrm{K}$ and $\mathrm{t}_{0}$ were estimated for the monthly length frequency data (sexes pooled) by fitting the equation, $\mathrm{Lt}=\mathrm{L}_{\infty}{ }^{*}\left[1-\mathrm{e}^{-\mathrm{K}\left(\mathrm{t}-\mathrm{t}_{0}\right)}\right]$ for non-seasonal VBG curve using the ELEFAN 1 technique available with LFDA ver. 5.0 of FMSP- Fish Stock Assessment Software (Hoggarth et al., 2006). The overall growth performance index (Phi prime) of the fish was estimated empirically (Munro and Pauly, 1983). The size at first capture was calculated by plotting cumulative percentages of sizes against size groups.

The length converted catch curve method (Pauly, 1983 ) and Beverton-Holt technique (Beverton and Holt, 1956) were adopted to estimate total mortality (Z) employing the routines in the LFDA version 5.0 of FMSP software and the average $\mathrm{Z}$ of both the methods was considered for stock assessment.

Natural mortality coefficient (M) of fish was determined using the empirical method (Pauly, 1980) considering $26^{\circ} \mathrm{C}$ as the mean surface water temperature in the Omani waters (Thangaraja, 1995). The difference between $\mathrm{Z}$ and $\mathrm{M}$ was taken as the fishing mortality (F). The exploitation rate (E) and exploitation ratio (U) were determined by the formulae F/Z (Sparre and Venema, 1992) and F/Z (1-e $\left.{ }^{-z}\right)$ (Ricker, 1975) respectively.

From the annual average yield (Y) of Indian mackerel for the years 2005-2009 in the Muscat region calculated at $735 \mathrm{t}(\mathrm{GoSO}, 2010)$, the standing stock (Y/F) and total stock $(\mathrm{Y} / \mathrm{U})$ were calculated.

The maximum sustainable yield (MSY) was determined by Cadima's estimator (Traodec, 1977). To estimate the predicted yield and biomass for the $\mathrm{F}$ values ranging from 0 to 5 and the likely $\mathrm{F}$ for MSY, the YIELD software in FMSP package was used (Hoggarth et al., 2006). All the input parameters required for the software were taken from the present study and equilibrium yield-per-recruit (Yw/R), total biomass-per-recruit (TB/R) and stock spawning biomass-per-recruit (SSB/R) were estimated for F-values ranging from 0 to 5 .

The value of $\mathrm{SSB}_{0}$ was allocated considering the length at first maturity of $R$. kanagurta along the Muscat coast (Zaki et al., 2011) and occurrence of various length groups in the catches during 2009. Beverton and Holt stock recruit relationship (SSR) was adopted.

\section{Results and discussion}

\section{Catches and length frequency distribution}

The estimated landings of Indian mackerel from Muscat coast during $2000-2009$ are given in Fig. 2. The catch ranged from $419 \mathrm{t}$ in 2002 to $1025 \mathrm{t}$ in 2007 and the annual average catch stood at $735 \mathrm{t}$.

The total length of fish in the commercial catches during 2007-2009 ranged from 12.1 to $34.5 \mathrm{~cm}$ (Fig. 3). There were two peaks in the sizes, the minor peak at $14-15 \mathrm{~cm}$ and the major at $27-28 \mathrm{~cm}$. Fish in the size groups from $23-24 \mathrm{~cm}$ to $30-31 \mathrm{~cm}$ contributed to about $71.4 \%$ in the total catches and the average size of fish at capture was calculated at $26.4 \mathrm{~cm}$.

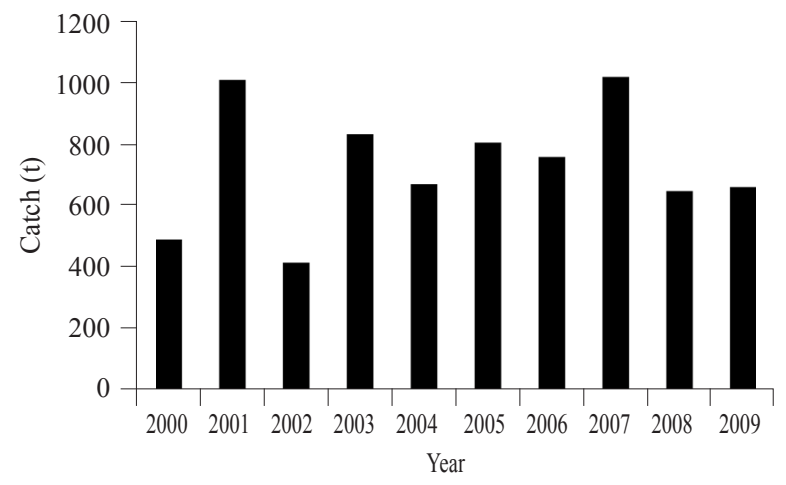

Fig. 2. Estimated catch of $R$. kanagurta from Muscat coast 


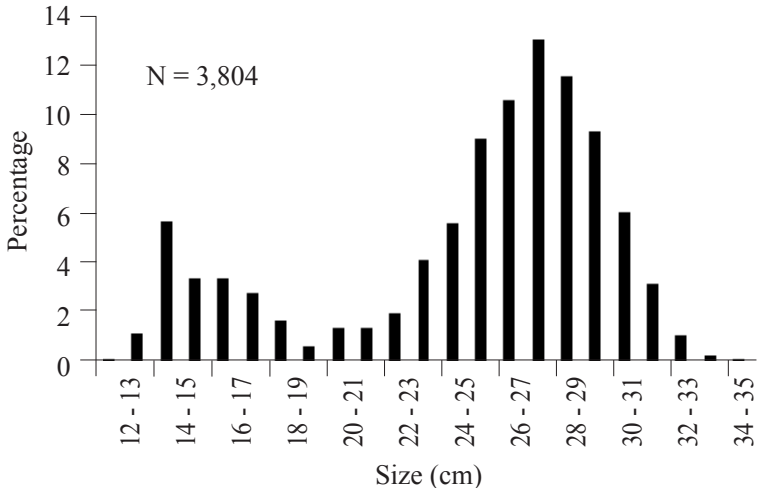

Fig. 3. Size frequency distribution of R. kanagurta in Muscat during 2007-09

The size of Indian mackerel in the commercial landings from the Sea of Oman ranged from 9.1 to $35 \mathrm{~cm}$ during 2007-2009 (Zaki et al., 2011). The estimated average size of fish at capture from Muscat presently was found to be larger $(26.4 \mathrm{~cm})$ than from Sohar coast $(23 \mathrm{~cm}$ ) bordering the Sea of Oman (Jayabalan et al., 2014). However, the average size of Indian mackerel landed at Mahout $(28 \mathrm{~cm})$ and Salalah $(27 \mathrm{~cm})$ were higher than from both Muscat and Sohar (Zaki et al., 2011) indicating the occurrence of larger individuals in the Arabian Sea than in the Sea of Oman. In general, the average size of the Indian mackerel from the Indian coasts bordering the Arabian Sea and Bay of Bengal appeared to be smaller than from Omani coasts (Noble et al., 1992; Yohannan and Sivadas, 2003; Rohit and Gupta, 2004; Abdussamad et al., 2006, 2010, Jayabalan, 2014).

\section{Length-weight relationship}

Though, the length-weight relationships indicated females to be slightly heavier than males, no significant difference existed $(p>0.05)$ between the relationships. Hence, the common equation for $R$. kanagurta from Muscat (Fig. 4) can be expressed as: $\mathrm{W}=0.0101 \mathrm{~L}^{3.0589}$ $\left(\mathrm{R}^{2}=0.9158\right)$.

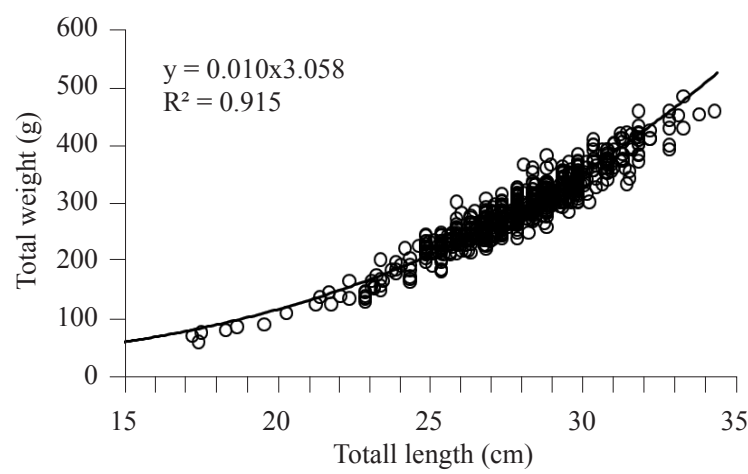

Fig. 4. Length-weight relationship in R. kanagurta in Muscat (Sexes pooled)
Common length-weight equations for males and females were proposed for $R$. kanagurta from Vizhijam in India (Gopakumar et al., 1991) and from Sohar in Oman (Jayabalan et al., 2014). However, separate lengthweight equations were suggested for males and females of the Indian mackerel from the Kakinada coast in India (Abdussamad et al., 2006).

The ' $b$ ' values of length-weight relationships of R. kanagurta vary between 3.010 and 3.475 in studies from various coasts of its distribution (Jones and Silas, 1962; Rafail, 1972; Luther, 1973; Sousa and Gislason, 1985; Tampubolon, 1988; Sanders and Morgan, 1989; Edwards and Shaher, 1991; Gopakumar et al., 1991; Noble et al., 1992; Pauly et al., 1996; Rohit et al., 1998; Mehanna, 2001; Abdurahiman et al., 2004; Rohit and Gupta, 2004; Moazzam et al., 2005; Abdussamad et al., 2006; Jayabalan et al., 2014). The 'b' value obtained in the present study lies within the range reported from earlier studies. As minor variation in the length-weight parameters would largely influence the stock structure, coast specific estimates of length-weight parameters are necessary for stock assessment.

\section{Age and growth}

The estimated $\mathrm{L}_{\infty}, \mathrm{K}$ and $\mathrm{t}_{0}$ values of $R$. kanagurta from Muscat were $37.54 \mathrm{~cm}, 1\left(\mathrm{y}^{-1}\right)$ and $-0.17 \mathrm{y}$ respectively (Fig. 5). The $\mathrm{L}_{\infty}$ and $\mathrm{K}$ values are higher in Muscat than in Sohar coast in Oman (Jayabalan et al., 2014). Growth parameters of $R$. kanagurta from earlier studies indicated that the parameters not only differed between the countries; but also, in different regions of the country and periods of study (Table 1). The present estimates of growth parameters are well within the ranges reported from earlier studies (Table 1).

Based on the VBG parameters, the expected lengths for different ages of $R$. kanagurta indicated higher growth

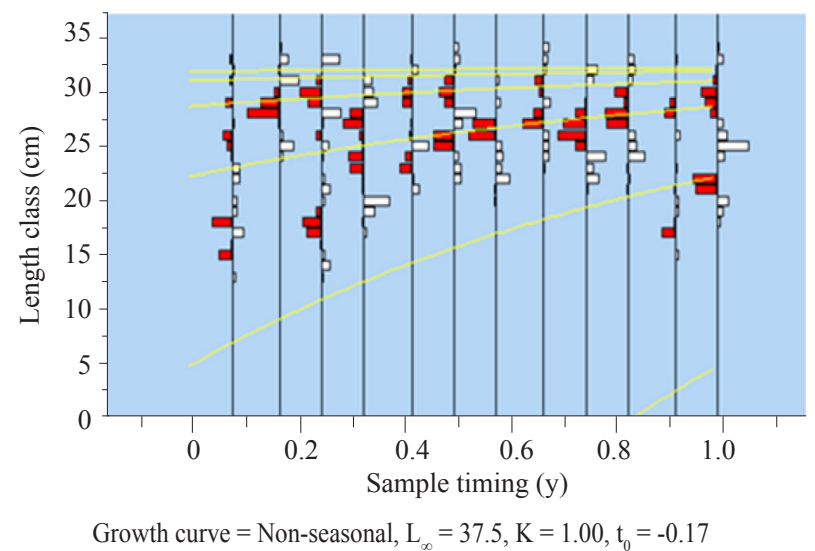

Fig. 5. VBG curves of $R$. kanagurta from Muscat by ELEFAN technique 
Table 1. Comparison of growth parameters of $R$. kanagurta from various studies

\begin{tabular}{|c|c|c|c|c|}
\hline Country/Region & $\mathrm{L}_{\infty}(\mathrm{cm})$ & $\mathrm{K}\left(\mathrm{y}^{-1}\right)$ & $\mathrm{t}_{0}(\mathrm{y})$ & Reference \\
\hline India & 31.6 & 0.6 & - & Rao et al. (1962) \\
\hline India & 39.0 & 0.74 & - & Luther (1973) \\
\hline India & 26.5 & 2.4 & - & Yohannan et al. (1998) \\
\hline India & 28.17 & 1.233 & - & Rohit et al. (1998) \\
\hline India (east coast) & 28.35 & 1.7 & - & Yohannan et al. (2002) \\
\hline India (west coast) & 28.50 & 1.78 & - & Yohannan et al. (2002) \\
\hline India & 30.7 & 1.8 & - & Rohit and Gupta (2004) \\
\hline India & 28.63 & 1.89 & -0.0023 & Abdussamad et al. (2006) \\
\hline India & 33.28 & 1.634 & 0.0018 & Abdussamad et al. (2010) \\
\hline Philippines & 38.0 & 0.8 & - & Guanco (1991) \\
\hline Seychelles & 31.7 & 0.64 & - & Lablache et al. (1988) \\
\hline Yemen & $32.3(\mathrm{FL})$ & 0.67 & -0.69 & Edwards and Shaher (1991) \\
\hline Egypt & 42.0 & 0.29 & -0.95 & Rafail (1972) \\
\hline Egypt & 40.0 & 0.23 & - & Sanders et al. (1984) \\
\hline Egypt & 32.15 & 0.57 & -0.053 & Mehanna (2001) \\
\hline Oman (Sohar) & 35.00 & 0.93 & -0.45 & Jayabalan et al. (2014) \\
\hline Oman (Muscat) & 37.54 & 1.00 & -0.17 & Present study \\
\hline
\end{tabular}

during first year $(27.7 \mathrm{~cm})$; while, the growth at $2^{\text {nd }}, 3^{\text {rd }}$ and $4^{\text {th }}$ years were $33.9,36.2$ and $37.1 \mathrm{~cm}$ respectively. However, lower growth rates for first, second, third and fourth year of age were reported from various coasts than in the present study (George and Banerji, 1964; Rao et al., 1962; Seshappa, 1969; Luther, 1973; Rafail, 1972; Mehanna, 2001; Abdussamad et al., 2006; Jayabalan et al., 2014).

The estimated phi-prime index stood at 3.15. This indicates comparatively faster growth in fish in Muscat than in Sohar (2.97) (Jayabalan et al., 2014). In the commercial catches in Muscat area, the fish in 0 year and $1+$ year were dominant.

\section{Mortality and exploitation rates}

Table 2 shows the estimates of Z, M, F, E and U of $R$. kanagurta from Muscat coast and all the values were comparable with the estimates reported earlier from the coast of Sohar (Jayabalan et al., 2014).

The annual $\mathrm{M}$ values of $R$. kanagurta varied from 1.00 to 2.61 in the Indian waters (Noble et al., 1992; Rohit et al., 1998; Rohit and Gupta, 2004; Abdussamad et al., 2006; 2010) and the present $M$ value is well within the above range. In Muscat, the estimated $\mathrm{F}$ was lower than $\mathrm{M}$ and the E value (0.46) was less than 0.5 (Gulland, 1971). These show that the stock is not harvested to its optimum level from the coast and hence there is scope for higher yield.

Table 2. Estimates of Z, M, F, E and U for R. kanagurta in the Sea of Oman

\begin{tabular}{lllllll}
\hline Centre & $\mathrm{Z}$ & $\mathrm{M}$ & $\mathrm{F}$ & $\mathrm{E}$ & $\mathrm{U}$ & Source \\
\hline Sohar & 2.848 & 1.58 & 1.268 & 0.45 & 0.42 & Jayabalan et al. (2014) \\
Muscat & 2.978 & 1.62 & 1.358 & 0.46 & 0.43 & Present study
\end{tabular}

Stock assessment and per-recruit analysis

The standing stock and annual stock were estimated at 577 and 1,809 $\mathrm{t}$ respectively. The MSY calculated by Cadima's formula was $859 \mathrm{t}$. The yield analysis indicated an initial biomass of $4173 \mathrm{t}$ and MSY of $1273 \mathrm{t}$ (Fig. 6). The increase in $\mathrm{F}$ from 0 showed the yield to increase proportionately and the MSY of $1273 \mathrm{t}$ was achieved at $\mathrm{F}=1.6$ and the corresponding biomass stood at $1854 \mathrm{t}$. Further increase in $\mathrm{F}$ showed the yield to decrease and at $\mathrm{F}=4$, the biomass was equal to $1153 \mathrm{t}$. The initial SSB of $3078 \mathrm{t}$ reduced to $1206 \mathrm{t}$ at the MSY level harvest. The SSB decreased further with increase in $\mathrm{F}$ and at $\mathrm{F}=4$, the SSB was just $651 \mathrm{t}$ which was equal to $21 \%$ of the initial value. The average annual catch of $783 \mathrm{t}$ in Muscat coast is lower than the estimated MSY. Further, the M $\left(1.62 \mathrm{y}^{-1}\right)$ was higher than $\mathrm{F}\left(1.358 \mathrm{y}^{-1}\right)$, while $\mathrm{E}$ stood at 0.46 . Hence, there is possibility for marginal increase in catches from the Muscat coast.

The $\mathrm{Yw} / \mathrm{R}, \mathrm{TB} / \mathrm{R}$ and $\mathrm{SSB} / \mathrm{R}$ of $R$. kanagurta in Muscat region are shown in Fig. 7. The $\mathrm{Yw} / \mathrm{R}$ at $\mathrm{F}=1.6$ was $48.0 \mathrm{~g}$. The TB/R, FB/R and SSB/R decreased with

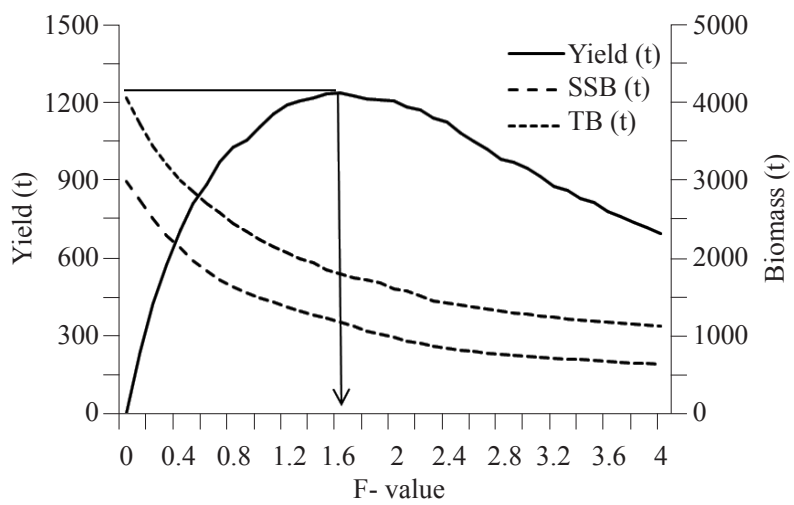

Fig. 6. Predicted yield, biomass and SSB of R. kanagurta in Muscat against different $\mathrm{F}$ 


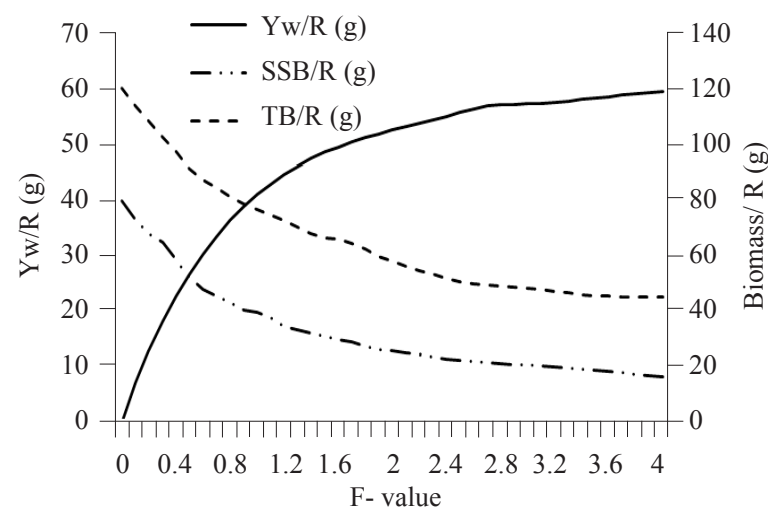

Fig. 7. $\mathrm{Yw} / \mathrm{R}, \mathrm{TB} / \mathrm{R}$, and $\mathrm{SSB} / \mathrm{R}$ of $R$. kanagurta in Muscat against different $\mathrm{F}$ values

increase in $\mathrm{F}$. At $\mathrm{F}=1$, the $\mathrm{TB} / \mathrm{R}, \mathrm{FB} / \mathrm{R}$ and $\mathrm{SSB} / \mathrm{R}$ were $74.2,39.9$ and $38.6 \mathrm{~g}$ respectively which decreased to $43.8,14.4$ and $16.0 \mathrm{~g}$ at $\mathrm{F}=4$.

Indian mackerel utilise both primary and secondary production as well as associate with larger carnivores in the food chain in the coastal waters (Yohannan and Sivadas, 2003). In the coastal upwelling areas, interannual variations in the abundance of plankton feeding small pelagic fishes are common (Krishnakumar et al., 2008). Hence, the annual fluctuations in the catches of Indian mackerel would be related to fishery independent factors.

Along the Muscat coast, the length at first maturity $\left(\mathrm{L}_{\mathrm{m}}\right)$ of $R$. kanagurta was calculated at $22.8 \mathrm{~cm}$ for males and $23.1 \mathrm{~cm}$ for females during 2007-08 and the corresponding values were 23.7 and $24 \mathrm{~cm}$ in males and females respectively during 2008-09 (Zaki et al., 2011). Since, the average size of fish at capture in Muscat was calculated at $26.4 \mathrm{~cm}$, there appears to be no fishery management concern at present. As the fish appears to grow to $27.7 \mathrm{~cm}$ at the end of first year, fish would attain maturity prior to the completion of first year of its life. Occurrence of mature fish for several months in the catches indicates that the fish is adapted to make use of any favourable environment for spawning in Omani waters (Zaki et al., 2011).

\section{Acknowledgements}

We are highly indebted to H. E. Dr. Hamed Al-Oufi, the Under Secretary of Fisheries Wealth, Ministry of Agriculture and Fisheries Wealth, Government of Sultanate of Oman, for his encouragement and suggestions during the study. We are also thankful to the Agriculture and Fisheries Development Fund, Government of Sultanate of Oman for generous funding support and other project colleagues for their technical help.

\section{References}

Abdurahiman, K. P., Harishnayak, T., Zacharia, P. U. and Mohamed, K. S. 2004. Length-weight relationship of commercially important marine fishes and shellfishes of the southern coast of Karnataka, India. Naga, 27(1\&2): 9-14.

Abdussamad, E. M., Kasim, H. M. and Achayya, P. 2006. Fishery and population characteristics of Indian mackerel, Rastrelliger kanagurta (Cuvier) at Kakinada. Indian J. Fish., 53(1): 77-83.

Abdussamad, E. M., Pillai, N. G. K., Kasim, H. M., Habeeb Mohamed, O. M. M. and Jeyabalan, K. 2010. Fishery, biology and population characteristics of Indian mackerel, Rastrelliger kanagurta (Cuvier) exploited along the Tuticorin coast. Indian J. Fish., 57(1): 17-21.

Beverton, R. J. H. and Holt, S. J. 1956. A review of methods for estimating mortality rates in exploited fish populations, with special reference to sources of bias in catch sampling. Rapp. P.V. Reun. CIEM, 140: 67-83.

Edwards, R. R. C. and Shaher, S. 1991. The biometrics of marine fishes from the Gulf of Aden. Fishbyte, 9(2): 27-29.

George, K. C. and Banerji, S. K. 1964. Age and growth studies on the Indian mackerel Rastrelliger kanagurta (Cuvier) with special reference to length frequency data collected at Cochin. Indian J. Fish., 11 A(2): 621-638.

Gopakumar, G., Pillai, N. G. K. and Omana, T. A. 1991. The fishery characteristics and biology of mackerel at Vizhinjam. J. Mar. Biol. Ass. India, 33(1\& 2): 107-114.

GoSO (Government of Sultanate of Oman) 2007. Fishery statistics book 2008. Fisheries Statistics and Information Department, Directorate General of Fisheries Research, Oman.

GoSO (Government of Sultanate of Oman) 2009. Fishery statistics book 2009. Fisheries Statistics and Information Department, Directorate General of Fisheries Research, Oman.

GoSO (Government of Sultanate of Oman) 2010. Fishery statistics book 2010. Fisheries Statistics and Information Department, Directorate General of Fisheries Research, Oman.

Guanco, M. R. 1991. Growth and mortality of Indian mackerel Rastrelliger kanagurta (Scombridae) in the Visayas Sea, Central Philippines. Fishbyte, 9(2): 13-15.

Gulland, J. A. 1971. The fish resources of the ocean. Fishing News (Books) Ltd., West Byfleet, for FAO, 255 pp.

Hoggarth, D. D., Abeyasekera, S., Arthur, R., Beddington, J. R., Burn, R. W., Halls, A. S., Kirkwood, G. P., McAllister, M., Medley, P., Mees, C. C., Pilling, G. M., Wakeford, R. and Welcomme, R. L. 2006. Stock assessment and fishery management - A framework guide to the FMSP stock assessment tools, FAO Fisheries Technical Paper No. 487, Rome, Italy, $261 \mathrm{pp}$. 
Jayabalan, N., Zaki, S., Al-Kiyumi, F., Al-Kharusi, L. and Al-Habsi, S. 2014. Age, growth and stock assessment of the Indian mackerel Rastrelliger kanagurta (Cuvier, 1817) along the Sohar coast of Oman. Indian J. Fish., 61(1): 1-6.

Jones, S. and Silas, E. G. 1962. Mackerel from the Andaman Sea. Proceedings of the Symposium on Scombroid Fishes, Marine Biological Association of India, Mandapam Camp, 12-15 January 1962, Part I, p. 255-282.

Krishnakumar, P. K., Mohamed, K. S., Asokan, P. K., Sathianandan, T. V., Zacharia, P. U., Abdurahiman, K. P., Shettigar, V. and Durgekar, R. N. 2008. How environmental parameters influenced fluctuations in oil sardine and mackerel fishery during 1926-2005 along the south-west coast of India? Mar. Fish. Infor. Serv. T\& E Ser., 198, 1-5.

Lablache, G., Augier de Moussac, G. and Jivan Shah, N. 1988. Summary of description of the artisanal fisheries and resources for the Seychelles. In: Sanders, M. J., Sparre, P. and Venema, S. C. (Eds.), Proceeding of the Workshop on the assessment of the fishery resources in the South-west Indian Ocean, FAO/UNDP: RAF/79/065/WP/41/88E, p. 116-141.

Luther, G. 1973. Observations on the fishery and biology of the Indian mackerel Rastrelliger kanagurta (Cuvier) from Andaman Islands. Indian J. Fish., 20(2): 425-447.

Mehanna, S. F. 2001. Population dynamics and fisheries management of the Indian mackerel Rastrelliger kanagurta in the Gulf of Suez, Egypt. J. KAU. Mar. Sci., 12: 217-229.

Moazzam, M., Osmany, H. B. and Zohra, K. 2005. Indian mackerel (Rastrelliger kanagurta) from Pakistan-I. Some aspects of biology and fisheries. Rec. Zool. Surv. Pakistan, 16: 58-75.

Munro, J. L. and Pauly, D. 1983. A simple method for comparing the growth of fishes and invertebrates, ICLARM Fishbyte, 1: 5-6.

Noble, A., Gopakumar, G., Pillai, N. G. K., Kulkarni, G. M., Kurup, K. N., Reuben, S., Sivadas, M. and Yohannan, T. M. 1992. Assessment of mackerel stock along the Indian coast. Indian J. Fish., 39: 11-24.

Pauly, D. 1980. On the interrelationships between natural mortality, growth parameters and mean environmental temperature in 175 fish stocks. Journal du Conseil international pour I' Exploration de la Mar, 39(2): 175-192.

Pauly, D. 1983. Length converted catch curves. A powerful tool for fisheries research in the tropics (Part I). ICLARM Fishbyte, 1(2): 9-13.

Pauly, D., Cabanban, A. and Torres Jr., F. S. B. 1996. In: Pauly, D. and Martosubroto, P. (Eds.), Fishery biology of 40 trawl-caught teleosts of western Indonesia. Baseline studies of biodiversity: the fish resource of western Indonesia. ICLARM Stud. Rev., 23: 135-216

Rafail, S. Z. 1972. Studies of Red Sea fisheries by light and purse-seine near Al-Ghardaqa. Bull. Inst. Ocean. Fish. (Cairo)., 2: 25-49.
Randall, J. E. 1995. Coastal fishes of Oman. University of Hawaii Press, Honolulu, HI, 439 pp.

Rao, V. Ramamohana, Sekharan, K. V. and Pradhan, M. J. 1962. On the mackerel fishery of the Mangalore area during the period 1957-1961. Indian J. Fish., 9(2): 653-678.

Ricker, W. E. 1975. Computation and interpretation of biological statistics of fish populations, Bull. Fish. Res. Bd. Canada, 191: 1-382.

Rohit Pratibha and Gupta, A. C. 2004. Fishery, biology and stock of the Indian mackerel Rastrelliger kanagurta off Mangalore-Malpe in Karnataka, India. J. Mar. Biol. Ass. India, 46(2): 185-191

Rohit Pratibha, Pillai, P. P., Gupta, A. C. and Preetha, K. 1998. Fishery and population characteristics of mackerel landed by trawlers along the Dakshina Kannada coast. Indian J. Fish., 45(1): 21-27.

Sanders, M. J. and Morgan, G. R. 1989. Review of fisheries resources of the Red Sea and Gulf of Aden. FAO Fish. Tech. Rep., 304, 138 pp.

Sanders, M. J., Kedidi, S. M. and Hegazy, M. R. 1984. Stock assessment for the Indian mackerel (Rastrelliger kanagurta) caught by purse seine from the Gulf of Suez and more southern Red Sea waters. FAO/UNDP/RAB/83/ 023/03, $42 \mathrm{pp}$.

Seshappa, G. S. 1969. The problem of age-determination in the Indian mackerel, Rastrelliger kanagurta, by means of scales and otoliths. Indian J. Fish., 16(1\& 2): 14-28.

Snedecor, G. W. and Cochran, W. G. 1967. Statistical methods, $6^{\text {th }}$ edn., Oxford and IBH Publishing Co., New Delhi.

Sousa, M. I. and Gislason, H. 1985. Reproduction, age and growth of the Indian mackerel, Rastrelliger kanagurta (Cuvier, 1816) from Sofala Bank, Mozambique. Rev. de Inv. pesq., (14): 1- 28.

Sparre, P. and Venema, S. C. 1992. Introduction to tropical fish stock assessment, part 1. Manual FAO Fisheries Technical Paper, 304: 1-337.

Tampubolon, G. H. 1988. Growth and mortality estimation of Indian mackerel Rastrelliger kanagurta in the Malacca Strait, Indonesia. In: Venema, S. C., Christensen, J. M. and Pauly, D. (Eds.), Contributions to tropical fisheries biology. FAO/DANIDA Follow-up Training Course on Fish stock assessment in the Tropics. Denmark, 1986 and Philippines, 1987, FAO Fish Rep., 389: 372-384.

Thangaraja, M. 1995. Hydrobiology off Oman. MSFC, Ministry of Agriculture and Fisheries, Muscat, Sultanate of Oman, Research Report No. 95-1: 153 pp.

Troadec, J. P. 1977. Methodes semi-quantitatives d'evaluation FAO Circ. Peches, 701: 131-141.

Yohannan, T. M. and Sivadas, M. 2003. The Indian mackerel. In: Mohan Joseph, M. and Jayaprakash, A. A. (Eds.), Status of exploited marine fishery resources of India. Central Marine Fisheries Research Institute, Kochi, p. 60-65. 
Yohannan, T. M., Balasubramanian, K. K. and Janaki, V. K. 1998. Comparison of the growth patterns of Indian mackerel and oil sardine. J. Mar. Biol. Ass. India, 40(1 \& 2): 205-208.

Yohannan, T. M., Ganga, U., Rohit, P., Pillai, P. P., Nair, P. N. R., Gopakumar, G., Kasim, H. M., Abdussamad, E. M., Sreenivasagan, K., Shanmugavel, A. and Sumithrudu, M. S. 2002. Stock assessment of mackerel in the Indian seas. In: Pillai, N. G. K., Menon, N. G., Pillai, P. P. and
Ganga, U. (Eds.), Management of scombroid fisheries. Central Marine Fisheries Research Institute, Kochi, p. 101-107.

Zaki, S., Jayabalan, N., Al-Kiyumi, F., Al-Kharusi, L., Al-Habsi, S. and Al-Marzouqi, A. 2011. Fishery, biology and population dynamics of three small pelagic fish species (Indian oil sardine Sardinella longiceps, Indian mackerel Rastrelliger kanagurta and Indian scad Decapterus russelli) from the Sultanate of Oman. Project Final Report- Part II. Ministry of Agriculture and Fisheries, Oman, 163 pp. 